\title{
MOTIVASI DAN PERSEPSI MAHASISWA PADA KEWIRAUSAHAN SEBAGAI PENINGKATAN PRESTASI BELAJAR MATA KULIAH KEWIRAUSAHAAN
}

\author{
Oleh: \\ Hardian Mursito \\ Program StudiPendidikan Ekonomi \\ FakultasIlmu Pendidikan dan PengetahuanSosial \\ Universitas Indraprasta PGRI \\ Email: \\ hardian.mursito@unindra.ac.id
}

\begin{abstract}
ABSTRAK
Penelitian membahas pengaruh motivasi berprestasi dan persepsi mahasiswa pada kewirausahaan terhadap prestasi belajar kewirausahaan. Jenis penelitian kuantitatif dengan metode penelitian yang digunakan adalah survey dengan analisis korelasi dan regresi, data tentang motivasi berprestasi dan persepsi mahasiswa diperoleh melalui angket, sedangkan data prestasi belajar menggunakan kisi-kisi dan soal. Teknik pengambilan sampel dilakukan secara prposional dan random dengan jumlah sampel 60 mahasiswa. Hasil penelitian diperoleh adalah: Terdapat pengaruh motivasi berprestasi dan persepsi mahasiswa pada kewirausahaan secara bersamasama terhadap prestasi belajar pada kewirausahaan. Terdapat pengaruh motivasi berprestasi terhadap prestasi belajar pada kewirausahaan. Terdapat pengaruh persepsi mahasiswa pada kewirausahaan terhadap prestasi belajar pada kewirausahaan. Dari hasil tersebut menunjukan motivasi mahasiswa secara maksimal akan memperoleh tingkat pencapaian prestasi belajar sedangkan persepsi mahasiswa pada kewirausahaan mampu mendorong mahasiswa mencapai kemampuan pengetahuan kewirausahaan
\end{abstract}

Kata Kunci: motivasi berprestasi, persepsi, prestasi belajar

\section{A. PENDAHULUAN}

Dalam dekade saat ini permasalahan bangsa Indonesia begitu kompleks, hampir dari semua aspek kehidupan menjadi masalah nasional. Tidak hanya bidang sosialekonomi saja,namun politik dan agama juga sudah mulai mencuat, hal ini ditandai dengan banyaknya aksi-aksi demonstrasi yang menimbulkan perselisihan antar beberapa kelompok dalam masyarakat. Suasana yang tidak kondusif ini menyebabkan krisis ekonomi berkepanjangan, meningkatnya jumlah pengangguran dan tindak kejahatan.Melihat kondisi tersebut pemerintah melalui kementerian Pendidikan Nasional menggalakan pendidikan kewirausahaan, khususnya untuk mahasiswa disemua disiplin ilmu dan siswa SMK. Bahkan untuk perguruan tinggi 
sangat dianjurkan untuk melakukan pembinaan langsung dan praktis kepada mahasiswanya untuk berwirausaha, misalnya dengan membentuk inkubator bisnis atau bentuk-bentuk pembinaan kewirausahaan yang lain.

Kegiatan kuliah kewirausahaan bukan hanya memberikan pandangan secara teoritis tetapi diharapkan dapat membentuk perilaku dan pola pikir seorang wirausahawan sebagai investasi modal mahasiswa dalam mempersiapkan entrepreneur. Akan tetapi ada pula pandangan sebagaian mahasiswa bahwa setelah menjadi sarjana adalah dapat bekerja sesuai dengan displin ilmu yang diperolehnya pada saat kuliah (Atmaja \& Margunani, 2016).

Bahkan betapa pentingya pendidikan kewirausahaan para pendidik kewirausahaan indonesia membuat pertemuan Roundtable Entrepreneur Educator. Pada pertemuan ke 2 REE tahun 2014 menghasilkan pengamatan adanya kesadaran bersama tentang pentingnya memberikan Pendidikan Kewirausahaan di berbagai bidang lembaga pendidikan dan jenjang pendidikan, adanya kebingungan tentang bagaimana merancang pendidikan kewirausahaan, adanya kecenderungan pemahaman bahwa umumnya keberhasilan berwirausaha di pahami dengan berhasilnya membangun perusahaan dan belum adanya action plan yang di sepakati (Purnomo, 2015).

Fenomena tersebut mengindikasikan peran pentingnya kewirausahaan bagi mahasiswa yang diukur dari prestasi belajarnya. Mahasiswa Universitas Indraprasta PGRI memiliki ide dan kreatifitas yang baik ini dapat di lihat dari kegiatan yang diselenggarakan oleh kordinator dosen pengampu mata kuliah kewirausahaan yaitu kegiatan Entrepreneur Day dimana mahasiswa menampilkan produk-produk hasil kreatifitasnya. Akan tetapi apakah kemampuan tersebut sejalan dengan motivasi dan persepsi mahasiswa mengenai kewirausahaan yang berdampak pada prestasi belajar mata kuliah kewirausahaan. Berdasarkan hal tersebut maka menjadikan dasar untuk mengetahui keterkaitan motivasi dan persepsi mahasiswa terhadap prestasi belajar kewirausahaan.

\section{B. KAJIAN PUSTAKA}

\section{Motivasi Berprestasi}

Motivasi adalah dorongan yang menyebabkan seseorang melakukan perbuatan untuk mencapai kepentingan dan kebutuhan atau tujuan tertentu yang di dasari adanya rangsangan dari faktor internal maupun eksternal (Cleopatra, 2015). Motivasi merupakan proses membangkitnya perilaku, mengarahkan dan memantapkan arah untuk mencapai tujuan yang di inginkan (Rosmiati et al., 2015)

Motivasi berprestasi seperti halnya motivasi pada umumnya, adalah suatu sistem yang terdiri dari kekuatan internal dan eksternal, yang merupakan kondisi yang mengaktifkan individu dalam menyelesaikan tugas tertentu, dengan berusaha semaksimal mungkin secara konsisten dan berkesinambungan. (Sujarwo, 2013) Mc Clelland memberikan pengertian motivasi berprestasi sebagai motivasi yang mendorong individu yang mencapai sukses, dan bertujuan untuk berhasil dalam kompetisi dan persaingan dengan beberapa ukuran keunggulan.

Kebutuhan berprestasi ditunjukan dengan usaha untuk selalu menyelesaikan tugas yang sulit sekalipun dengan baik dan mandiri, menanggulangi kesulitan- 
kesulitan yang menghalangi, mencapai standar tinggi, serta keberanian untuk melakukan persaingan (Haryani \& Tairas, 2014).

Dari pengertian tersebut motivasi berprestasi merupakan dorongan yang menjadikan sikap unggul, berani dengan tujuan mencapai prestasi. Seseorang yang memiliki motivasi berprestasi selalu ingin bersaing untuk mencapai suatu tujuan dengan mengutamakan standar tertentu, dengan bekerja keras, melakukan suatu pekerjaan dengan baik, dan selalu memilih yang terbaik.

\section{Persepsi Mahasiswa pada Kewirausahaan}

Manusia pada hakekatnya memiliki berbagai dimensi dalam hidupnya seperti akal, bentuk tubuh, sifat dan kepribadian. Sehingga faktor - faktor tersebut menimbulkan berbagai macam perbedaan termasuk dalam menginterpretasikan informasi. Sehingga persepsi di interpretasikan dari rangsanagan panca indera yang merupakan hasil dari pemrosesan informasi (Iriawan S, 2013).

Persepsi merupakan proses dari penginderaan yang menyangkut pesan atau informasi ke dalam otak manusia kemudian menjadi intergrated dari individu terhadap stimulus yang diterimanya. Stimulus yang diterima kemudian di interpretasikan sehingga dapat dipahami dan mengerti tentang stimulus yang di terimanya (Pinaryo, 2016).

Pendidikan kewirausahan di perguruan tinggi di Indonesia sangat beragam, bahkan perguruan tinggi di negara lain. (Susilaningsih, 2015) Salah satu contoh pendidikan kewirausahaan di singapura dikembangkan dengan menggunakan knowledge based sehingga terjadi transisi dari investmen driven economy menuju innovation driven. Bahkan fokus pendidikan kewirausahaan adalah pada entrepreneurial intention yaitu intensi kewirausahaan akan timbul bila ia memiliki pengetahuan, harapan untuk berhasil dan kepercayaan bahwa dirinya mampu (Rahmadani.,et al.,2018).

Mahasiswa perlu merealisasikan ide dan konsep bisnis melalui program kewirausahaan yang sudah di fasilitasi oleh pihak universitas yaitu adanya Program Kreativitas Mahasiswa. Program tersebut dapat menjadi alternatif yang dipilih mahasiswa untuk merealisasikan ide dan konsep wirausaha yang dimilikinya dalam bentuk aktivitas wirausaha (Rahmadani.,et al. 2018).

Sehingga persepsi mahasiswa pada kewirausahaan merupakan kemampuan indera mahasiswa menafsirkan atau menginterpretasikan terhadapa objek yang diamati (peluang dan pasar) kemudian dikembangkan menjadi ide atau konsep perencanaan bisnis.

\section{Prestasi Belajar Mata Kuliah Kewirausahaan}

Prestasi belajar adalah kemampuan yang dicapai seseorang dalam melakukan kegiatan tertentu. Prestasi merupakan hasil yang telah dicapai oleh belajar, yaitu tingkah laku yang dinyatakan dalam bentuk skor (Novauli. M, 2015).

Hasil studi empiris dari Sari dan Habsari diperoleh hasil yang menunjukkan kontribusi mata kuliah kewirausahaan pada penumbuhan jiwa entrepreneurship, menumbuhkan wawasan berwirausaha, menumbuhkan mental dan semangat wirausaha, menumbuhkan semangat membangun bisnis yang beretika dan meningkatkan motivasi mahasiswa dalam berwirausaha (Sari \& Habsari, 2016). 
Sekaligus (Asfiatul, 2013) memperoleh hasil penelitian peserta didik mendapatkan skor tertinggi dari hasil analisis aspek-aspek perencanaan usaha dan faktor-faktor kegagalan wirausaha, sedangkan skor terendah diperoleh dari hasil analisis faktor-faktor kepuasan pelanggan dan menyusun proposal bisnis. Dalam hal ini pendidikan dan pelatihan kewirausahaan lebih tinggi dari pada prestasi belajar kewirausahaan.

Perkembangan yang diharapkan dalam proses belajar ialah adanya perubahan yang terjadi setelah kegiatan pembelajaran berlangsung. Belajar dianggap sebagai proses perubahan perilaku dari pengalaman dan latihan bukanlah sekadar mengumpulkan pengetahuan saja, namun juga memahami pengetahuan yang diterima (Yuniawatika \& Luh, 2016).

Prestasi belajar merupakan hasil dari usaha yang telah dilakukan mahasiswa dalam proses perubahan tingkah laku yang dinyatakan dalam bentuk pemahaman, penguasaaan, penggunaan dan penilaian terhadap sikap nilai, pengetahuan dan kecakapan dasar, serta perkembangan keterampilan yang lebih memuaskan setelah mengalami proses pembelajaran (Febianti \& Joharudin, 2017). Sehingga prestasi belajar mata kuliah kewirausahaan adalah bukti keberhasilan yang dicapai melalui proses pembelajaran kewirausahaan yang menjadikan perubahan tingkah laku dalam bentuk pemahaman secara komprehensif, pengetahuan dalam konsep perencanaan dan pengembangan keahlian sebagai wirauasaha.

\section{METODE PENELITIAN}

Metode yang digunakan dalam penelitian ini adalah survai dengan teknik korelasional. Teknik pengambilan sampel dalam penelitian ini adalah dilakukan secara proporsional dan random. Mengingat jumlah populasi 283 peserta mata kuliah kewirausahaan maka jumlah anggota sampel yang diambil oleh peneliti berjumlah 60 mahasiswa.

Sumber data untuk variabel motivasi berprestasi dan persepsi pada kewirausahaan seluruh variabel di atas adalah jawaban responden (mahasiswa) atas butir-butir pertanyaan yang ada dalam angket/kuesioner.

Sedangkan data untuk variable prestasi belajar matakuliah kewirausahaan adalah teknik dokumentasi nilai akhir mata kuliah Kewirausahaan II semester Genap tahun akademik 2015 untuk Fakultas Pendidikan Ilmu Pengetahuan Sosial.

Teknik analisis data menggunakan korelasional dan regeresi ganda, dengan melalui uji persyaratan analisis data menggunakan uji normalitas dan linearitas. Sedangkan masing-masing variabel akan diolah dan dianalisis ukuran pemusatan dan letak seperti mean, modus, dan median serta simpangan baku dengan statistik deskriptif yang seluruh perhitungan menggunakan bantuan program komputer SPSS 17.0. 


\section{HASIL DAN PEMBAHASAN}

\section{Deskripsi Data}

Tabel 1.

Descriptive Statistics

\begin{tabular}{lcccccc}
\hline & N & Min. & Max. & Mean & Median & $\begin{array}{c}\text { Std. } \\
\text { Deviation }\end{array}$ \\
\hline $\begin{array}{l}\text { Motivasi_Berpres tasi } \\
\begin{array}{l}\text { Persepsi_MHS__pada_Kewirausa } \\
\text { haan }\end{array}\end{array}$ & 60 & 62 & 114 & 93.2500 & 94 & 12.37223 \\
$\begin{array}{l}\text { Prestasi_Belajar_pada_Kewirausa } \\
\text { haan }\end{array}$ & 60 & 46 & 95 & 73.4667 & 76 & 12.54479 \\
Valid N (listwise) & 60 & & & & \\
\hline \multicolumn{7}{c}{ Sumber: Data sekunder diolah }
\end{tabular}

Sumber: Data sekunder diolah

\section{Pembahasan/Interpretasi Hasil Penelitian}

\section{Pengaruh Motivasi Berprestasi dan Persepsi Mahasiswa pada Kewirausahaan secara bersama-sama terhadap Prestasi Belajar pada Kewirausahaan}

Dari deskripsi data setelah dilakukan analisis korelasi diperoleh koefisien korelasi sebesar 0,79 dan koefisien determinasi sebesaar $62,5 \%$, setelah dilakukan pengujian dengan program SPSS terbukti bahwa koefisien korelasi tersebut signifikan. Hal ini berarti bahwa terdapat pengaruh variabel bebas $\mathrm{X}_{1}$ (Motivasi Berprestasi) dan $\mathrm{X}_{2}$ (Persepsi Mahasiswa pada Kewirausahaan) secara bersamasama terhadap variabel terikat Y (Prestasi Belajar pada Kewirausahaan).

Sedangkan dari analisis regresi diperoleh persamaan garis regresi $\widehat{\mathbf{Y}}=$ $8.152+0,415 X_{1}+0,324 X_{2}$. Nilai konstanta $=-8.152$ menunjukkan bahwa dengan motivasi Berprestasi dan persepsi mahasiswa pada Kewirausahaan paling rendah sulit bagi mahasiswa tersebut untuk bisa meraih prestasi belajar yang baik, sedangkan nilai koefisien regresi sebesar 0,415 dan 0,324 menunjukkan bahwa terdapat pengaruh positif variabel bebas $\mathrm{X}_{1}$ (Motivasi Berprestasi) dan $\mathrm{X}_{2}$ (Persepsi Mahasiswa pada Kewirausahaan) secara bersama-sama terhadap variabel terikat $Y$ (Prestasi Belajar pada Kewirausahaan), setiap ada kenaikan satu nilai mikap siswa pada matakuliah Kewirausahaan maka akan terdapat kenaikan Prestasi Belajar pada Kewirausahaan sebesar 0,415, dan setiap ada kenaikan satu nilai Persepsi Mahasiswa pada Kewirausahaan maka akan terdapat kenaikan Prestasi Belajar pada Kewirausahaan sebesar 0,324.

Setelah dilakukan pengujian linieritas garis regresi dengan menggunakan program SPSS diperoleh bahwa garis regresi tersebut linier. Dari pengujian signifikansi koefisien regresi yang juga dilakukan dengan program SPSS diperoleh bahwa koefisien regresi tersebut signifikan, yang berarti benar bahwa terdapat pengaruh yang positif variabel bebas $\mathrm{X}_{1}$ (Motivasi Berprestasi) dan $\mathrm{X}_{2}$ (Persepsi Mahasiswa pada Kewirausahaan) secara bersama-sama terhadap variabel terikat $Y$ (Prestasi Belajar pada Kewirausahaan).

Menurut sintesis teori, motivasi berprestasi adalah kondisi psikologik yang mendorong seseorang untuk melakukan aktivitas tertentu atau merupakan dorongan dari dalam guna menghasilkan sesuatu yang lebih baik atau yang terbaik, yaitu 
mencapai prestasi dalam hubungannya dengan standar keunggulan. Persepsi pada kewirausahaan adalah gambaran yang ada dalam pikiran mahasiswa sesuai pengamatan, pemahaman dan penilaian mereka terhadap matakuliah kewirausahan yang didasari oleh pengetahuan dan pengalamanya. Sedangkan prestasi belajar Kewirausahaan adalah tingkat pencapaian kemampuan pengetahuan mahasiswa pada materi ilmu kewirausahaan, serta pencapaian ketrampilan dan sikap yang terkait dengan wawasan tentang ilmu kewirausahaan.

Dengan motivasi berprestasi yang tinggi yang dimiliki seorang siswa maka siswa tersebut akan berusaha semaksimal mungkin untuk meraih prestasi setinggitingginya, termasuk dalam meraih prestasi dalam belajar. Dia akan berusaha mengikuti setiap proses pembelajaran dengan baik, selalu berusaha meningkatkan pengetahuan, pemahaman, keterampilan, dan nilai sikapnya dalam belajar yang akhirnya prestasi belajar akan meningkat. Dengan memiliki persepsi yang positif pada ilmu kewirausahaan serta kebutuhan akan teori-teori atau ilmu tentang kewirausahaan yang dilatarbelakangi oleh keinginan, semangat, dan motivasi untuk berwirausahaa maka mahasiswa akan cenderung untuk mengikuti perkuliahan dengan seksama, semangat belajar akan tumbuh dengan baik, serta menekuni ilmu kewirausahaan tersebut. Jika ketekunan, motivasi dan semangat belajar tinggi maka niscaya prestasi belajar yang tinggi pun bisa diraih.

Dari informasi kuantitatif dan teori tersebut peneliti berkesimpulan bahwa Motivasi Berprestasi dan Persepsi Mahasiswa pada Kewirausahaan mempunyai pengaruh yang signifikan secara bersama-sama terhadap Prestasi Belajar pada Kewirausahaan.

\section{Pengaruh Motivasi Berprestasi terhadap Prestasi Belajar pada Kewirausahaan}

Dari pengujian hipotesis diperoleh bahwa nilai Sig $=0.000$ dan thitung $=4,95$, sedangkan $t_{\text {tabel }}=1,68$. Karena nilai Sig $<0,05$ dan $t_{\text {hitung }}>t_{\text {tabel }}$ maka $\mathrm{H}_{0}$ di tolak yang berarti terdapat pengaruh yang signifikan variabel bebas $\mathrm{X}_{1}$ (Motivasi Berprestasi) terhadap variabel terikat Y (Prestasi Belajar pada Kewirausahaan).

Menurut sintesis, motivasi berprestasi adalah kondisi psikologik yang mendorong seseorang untuk melakukan aktivitas tertentu atau merupakan dorongan dari dalam guna menghasilkan sesuatu yang lebih baik atau yang terbaik, yaitu mencapai prestasi dalam hubungannya dengan standar keunggulan. Sedangkan prestasi belajar Kewirausahaan adalah tingkat pencapaian kemampuan pengetahuan mahasiswa pada materi ilmu kewirausahaan, serta pencapaian ketrampilan dan sikap yang terkait dengan wawasan tentang ilmu kewirausahaan.

Dengan motivasi berprestasi yang tinggi yang dimiliki seorang siswa maka siswa tersebut akan berusaha semaksimal mungkin untuk meraih prestasi setinggitingginya, termasuk dalam meraih prestasi dalam belajar. Dia akan berusaha mengikuti setiap proses pembelajaran dengan baik, selalu berusaha meningkatkan pengetahuan, pemahaman, keterampilan, dan nilai sikapnya dalam belajar yang akhirnya prestasi belajar akan meningkat.

Dari informasi kuantitatif dan teori tersebut maka peneliti berkesimpulan bahwa Motivasi Berprestasi mempunyai pengaruh yang positif dan signifikan terhadap Prestasi Belajar pada Kewirausahaan. 


\section{Pengaruh Persepsi Mahasiswa pada Kewirausahaan $\left(\mathbf{X}_{2}\right)$ terhadap Prestasi Belajar pada Kewirausahaan (Y)}

Dari pengujian hipotesis diperoleh bahwa nilai $\operatorname{Sig}=0.000$ dan $t_{\text {hitung }}=5,903$, sedangkan $t_{\text {tabel }}=1,67$. Karena nilai Sig $<0,05$ dan $t_{\text {hitung }}>t_{\text {tabel }}$ maka $H_{0}$ di tolak yang berarti terdapat pengaruh yang signifikan variabel bebas $\mathrm{X}_{2}$ (Persepsi Mahasiswa pada Kewirausahaan) terhadap variabel terikat Y (Prestasi Belajar pada Kewirausahaan).

Menurut sintesis teori, persepsi pada Kewirausahaan adalah gambaran yang ada dalam pikiran mahasiswa sesuai pengamatan, pemahaman dan penilaian mereka terhadap matakuliah kewirausahan yang didasari oleh pengetahuan dan pengalamanya. Sedangkan prestasi belajar Kewirausahaan adalah tingkat pencapaian kemampuan pengetahuan mahasiswa pada materi ilmu kewirausahaan, serta pencapaian ketrampilan dan sikap yang terkait dengan wawasan tentang ilmu kewirausahaan.

Dengan memiliki persepsi yang positif pada ilmu kewirausahaan serta kebutuhan akan teori-teori atau ilmu tentang kewirausahaan yang dilatarbelakangi oleh keinginan, semangat, dan motivasi untuk berwirausahaa maka mahasiswa akan cenderung untuk mengikuti perkuliahan dengan seksama, semangat belajar akan tumbuh dengan baik, serta menekuni ilmu kewirausahaan tersebut. Jika ketekunan, motivasi dan semangat belajar tinggi maka niscaya prestasi belajar yang tinggi pun bisa diraih. Dari informasi kuantitatif dan teori tersebut maka peneliti berkesimpulan bahwa Persepsi Mahasiswa pada Kewirausahaan mempunyai pengaruh yang positif dan signifikan terhadap Prestasi Belajar pada Kewirausahaan.

\section{E. KESIMPULAN}

Berdasarkan hasil pengujian hipotesis terdapat pengaruh motivasi berprestasi dan persepsi mahasiswa pada kewirausahaan terhadap prestasi belajar kewirausahaan. Sekaligus menunjukkan pembuktian bahwa terdapat peran motivasi dalam meningkatkan prestasi belajar mata kuliah kewirausahaan begitu pula peran persepsi mahasiswa pada kewirausahaan akan meningkatkan prestasi belajar pada mata kuliah kewirausahaan. Sedangkan dalam prestasi belajar menunjukan kemampuan mahasiswa dalam membuat perencanaan bisnis yang termuat dalam rencana pembelajaran dibawah bimbingan dosen pengampu mata kuliah kewirausahaan yang berisi elemen-elemen pemasaran, keuangan, perilaku konsumen dan elemen lainnya dalam mendukung perencanaan bisnis yang baik. Pencapaian prestasi belajar mahasiswa tersebut dalam kemampuan membuat perencanaan bisnis menghasilkan ide dan kreatifitas dalam membuat produk, bahkan hasil produk tersebut dipasarkan dalam kegiatan Entrerpreneur Day yang di selenggarakan tiap tahun oleh Universitas Indraprasta PGRI. 


\section{DAFTAR PUSTAKA}

Asfiatul, F. (2013). Pengaruh Pendidikan \& Pelatihan, Prestasi Belajar Kewirausahaan terhadap Sikap Kewirausahaan Peserta didik SMK N 1 Cerme. Jurnal Kebijakan Dan Pengembangan Pendidikan, 1, 173-184.

Atmaja T.A \& Margunani. (2016). PENGARUH PENDIDIKAN KEWIRAUSAHAAN DAN AKTIVITAS WIRAUSAHA TERHADAP MINAT BERWIRAUSAHA MAHASISWA UNIVERSITAS NEGERI SEMARANG. Economic Education Analysis Journal, 5 (3), 774-787.

Cleopatra, M. (2015). Pengaruh Gaya Hidup dan Motivasi Belajar terhadap Prestasi Belajar Matematika. Formatif: Jurnal Ilmiah Pendidikan MIPA, 5, 168-181. https://doi.org/10.30998/formatif.v5i2.336

Febianti, Y. N., \& Joharudin, M. (2017). FAKTOR-FAKTOR EKSTERN YANG MEMPENGARUHI PRESTASI BELAJAR MAHASISWA. Edunomic Jurnal Pendidikan Ekonomi, 5, 76-88. https://doi.org/10.33603/ejpe.v5i2.246

Haryani, R., \& Tairas. (2014). Motivasi Berprestasi pada Mahasiswa Berprestasi dari Keluarga Tidak Mampu secara Ekonomi. Jurnal Psikologi Dan Perkembangan, 3 No 1, 30-36.

Iriawan S, A. (2013). PERSEPSI MAHASISWA TENTANG PERBANKAN SYARI ' AH ( STUDI KASUS MAHASISWA FAKULTAS EKONOMI DAN BISNIS UNISNU JEPARA ) Shalihul Aziz Widya Iriawan Universitas Islam Nahdlatul Ulama Jepara Email : aziz.widya85@gmail.com. Jurnal Dinamika Ekonomi \& Bisnis, 13 No1, 82-93. https://doi.org/https://doi.org/10.34001/jdeb.v13i1.396

Novauli. M, F. (2015). KOMPETENSI GURU DALAM PENINGKATAN PRESTASI BELAJAR PADA SMP NEGERI DALAM KOTA BANDA ACEH. Jurnal Administrasi Pendidikan : Program Pascasarjana Unsyiah, 3 No 1, 45-67.

Pinaryo. (2016). PERSEPSI MAHASISWA UNIVERSITAS MUHAMMADIYAH PONOROGO TERHADAP PROGRAM KEWIRAUSAHAAN MAHASISWA. ARISTO, 2(2), 53-66. https://doi.org/10.24269/ars.v2i2.22

Purnomo, M. (2015). DINAMIKA PENDIDIKAN KEWIRAUSAHAAN: PEMETAAN SISTEMATIS TERHADAP PENDIDIKAN, PENGAJARAN DAN PEMBELAJARAN KEWIRAUSAHAAN. Jurnal Dinamika Manajemen, 6 No 1, 97 120. https://doi.org/10.15294/jdm.v6i1.4300

Rahmadani, R., Suwatno., Machmud, A. (2018). ANALISIS FAKTOR-FAKTOR YANG MEMPENGARUHI PENDIDIKAN KEWIRAUSAHAAN(ENTREPRENEURSHIP EDUCATION) DI PERGURUAN TINGGI NEGERI KOTA BANDUNG. SOSIODIDAKTIKA: Social Science Education Journal, 5 No 1, 47-53. 
https://doi.org/10.15408/sd.v1i1.9522

Rosmiati, R., Junias, D. T. S., \& Munawar, M. (2015). SIKAP, MOTIVASI, DAN MINAT BERWIRAUSAHA MAHASISWA. Jurnal Manajemen Dan Kewirausahaan (Journal of Management and Entrepreneurship), 17 No 1, 21-30. https://doi.org/10.9744/jmk.17.1.21-30

Sari, N. E., \& Habsari, N. T. (2016). PENGARUH MATA KULIAH KEWIRAUSAHAAN TERHADAP MINAT BER-ENTREPRENEUR. EQUILIBRIUM : Jurnal Ilmiah Ekonomi Dan Pembelajarannya, 4 No 2, 135-143. https://doi.org/10.25273/equilibrium.v4i2.654

Sujarwo. (2013). Motivasi Berprestasi sebagai Salah Satu Perhatian dalam Memilih Strategi Pembelajaran. Journal of Chemical Information and Modeling, 4 no 2, 33-44.

Susilaningsih, S. (2015). PENDIDIKAN KEWIRAUSAHAAN DI PERGURUAN TINGGI: PENTINGKAH UNTUK SEMUA PROFESI? Jurnal Economia, 11 No 1, 1-9. https://doi.org/10.21831/economia.v11i1.7748

Yuniawatika,\& Nuraeni, Sakinah, Luh, N. (2016). Pengaruh Pembelajaran Strategi REACT terhadap Peningkatan Kemampuan Mahasiswa PGSD tentang Koneksi Matematis. Ilmu Pendidikan: Jurnal Kajian Teori Dan Praktik Kependidikan, 1 No2, 99-105. https://doi.org/10.17977/um027v1i22016p100 